University of Nebraska - Lincoln

DigitalCommons@University of Nebraska - Lincoln

Nebraska Cooperative Fish \& Wildlife Research Nebraska Cooperative Fish \& Wildlife Research Unit -- Staff Publications

2004

\title{
Relationship between Lake-Record Weights of Fishes and Reservoir Area and Growing Season
}

Gene R. Wilde

Texas Tech University, gene.wilde@ttu.edu

Kevin L. Pope

University of Nebraska-Lincoln, kpope2@unl.edu

Follow this and additional works at: https://digitalcommons.unl.edu/ncfwrustaff

Part of the Other Environmental Sciences Commons

Wilde, Gene R. and Pope, Kevin L., "Relationship between Lake-Record Weights of Fishes and Reservoir Area and Growing Season" (2004). Nebraska Cooperative Fish \& Wildlife Research Unit -- Staff Publications. 87.

https://digitalcommons.unl.edu/ncfwrustaff/87

This Article is brought to you for free and open access by the Nebraska Cooperative Fish \& Wildlife Research Unit at DigitalCommons@University of Nebraska - Lincoln. It has been accepted for inclusion in Nebraska Cooperative Fish \& Wildlife Research Unit -- Staff Publications by an authorized administrator of DigitalCommons@University of Nebraska - Lincoln. 


\title{
Relationship between Lake-Record Weights of Fishes and Reservoir Area and Growing Season
}

\author{
Gene R. Wilde* and Kevin L. Pope \\ Wildlife and Fisheries Management Institute, Mail Stop 2125, \\ Texas Tech University, Lubbock, Texas 79409, USA
}

\begin{abstract}
We used information from an angler recognition program to assess the relationship between lake-record weights of freshwater fishes captured by Texas anglers and two predictors of fish production and growth: reservoir surface area and growing-season length. The lake-record weights of two species, largemouth bass Micropterus salmoides and flathead catfish Pylodictis olivaris, were directly related to the logarithm of surface area. The record weights of all species studied were unrelated to growing-season length. Regardless of the statistical significance of individual correlations, there was a significant excess of positive correlations across all species between lake-record weights of fish and $\log$ surface area. This indicates the presence of a general relationship between the record weights of fish and reservoir area. Our results suggest that record weights of fish may be constrained by reservoir surface area.
\end{abstract}

The goal of fishery management is to provide opportunities for quality recreational fishing (Driver and Cooksey 1980). To achieve this goal, fisheries must be managed to produce a variety of experiences or "products" (Driver 1985) because anglers differ in their species preferences (Spencer 1993; Wilde and Ditton 2000), interest in harvesting or releasing captured fish (Fedler and Ditton 1986; Fisher 1997; Wilde et al. 1998), and preferences for the number and size of fish captured (Hudgins 1984; Petering et al. 1995). Catching trophy fish is not a primary motive for most anglers (Fedler and Ditton 1994; Wilde and Ditton 1994, 2000). Nevertheless, there is considerable angler interest in catching trophy-sized fish (e.g., Horton and Gilliland 1994; Hughes and Wood 1996), particularly among anglers who participate in tournaments (Falk et al. 1989; Wilde et al. 1998). To accommodate this interest, managers have attempted to increase the maximum size of fish through use of restrictive regulations, prey introductions, and genetic manipulation of fish populations (Gilliland and Whitaker 1990; Cofer 1994; Hughes and Wood 1996; Wilson and Dicenzo 2002). Although there is no consensus as to

\footnotetext{
* Corresponding author: gene.wilde@ttu.edu
}

Received May 20, 2003; accepted September 24, 2003 what constitutes a trophy-sized fish, one operational definition is that a fish large enough to be recorded as having a state- or water-body-record weight can be considered a trophy (but see Gabelhouse (1984) for an alternative definition).

Many fishery management agencies have developed angler recognition programs that give "awards to anglers who submit official affidavits for the catch of large fish", (Quinn 1987). A primary purpose of angler recognition programs is to stimulate interest and participation in recreational angling, but information collected as part of these programs also has been used to document changes in the maximum size of angled fish and to monitor fishery quality (e.g., Forshage et al. 1990). Beyond such descriptive uses, however, this information has received relatively little attention. In particular, we are aware of no analyses other than those of Modde and Scalet (1985) that attempt to ascertain relationships between the presence and size of trophy fish and causal factors (as suggested by Quinn 1987) that might guide agency efforts to increase the number and size of trophy fish available to anglers. In this paper we present an analysis of the relationship between lake-record weights of fishes caught by anglers in reservoirs and two indices of fish production and growth to determine whether the maximum weight of fishes can be predicted from reservoir characteristics.

\section{Methods}

We obtained lake-record weights of freshwater fish from the Texas Parks and Wildlife Department website (http://www.tpwd.state.tx.us/fish/infish/records/ -freshwater/arrwbr.htm) on 3 August 2002 (Table 1). Because we anticipated differences in growth between fish captured from reservoirs and rivers as well as difficulties in obtaining meaningful measures of surface area for rivers, we studied only records for reservoir populations. We retained for analysis data for 13 species and 1 hybrid (hybrid striped bass) for which at least 25 records were available from reservoirs. All fish were captured by anglers using rod and reel. We correlated lake-record weights of fish with two predictors of fish pro- 
TABLE 1.-Lake record weights of fish, reservoir surface area, growing-season length, and correlations between lakerecord weights of fish and $\log _{10}$ surface area and growing-season length for 13 species and 1 hybrid of fish captured by anglers from Texas reservoirs. A single asterisk indicates significance $(P \leq 0.05)$ for an individual correlation; two asterisks indicate tablewide significance $(P \leq 0.05)$ based on the sequential Bonferroni adjustment.

\begin{tabular}{|c|c|c|c|c|}
\hline \multirow[b]{2}{*}{ Species } & \multirow[b]{2}{*}{$N$} & \multicolumn{2}{|c|}{ Record weight (g) } & \multirow{2}{*}{$\frac{\text { Surface area (ha) }}{\text { Minimum }}$} \\
\hline & & Minimum & Maximum & \\
\hline Black crappie Pomoxis nigromaculatius & 37 & 226 & 1,670 & 20.2 \\
\hline Blue catfish Ictalurus furcatus & 27 & 824 & 41,629 & 21.0 \\
\hline Bluegill Lepomis macrochirus & 66 & 27 & 819 & 0.8 \\
\hline Channel catfish Ictalurus punctatus & 61 & 208 & 12,986 & 0.4 \\
\hline Common carp Cyprinus carpio & 30 & 398 & 16,403 & 5.3 \\
\hline Flathead catfish Pylodictis olivaris & 47 & 1,195 & 44,344 & 4.0 \\
\hline Largemouth bass Micropterus salmoides & 196 & 380 & 8,226 & 1.2 \\
\hline Longear sunfish Lepomis megalotis & 25 & 18 & 217 & 1.2 \\
\hline Redear sunfish Lepomis microlophus & 27 & 18 & 1,353 & 0.4 \\
\hline Smallmouth bass Micropterus dolomieu & 31 & 561 & 3,588 & 202.4 \\
\hline Striped bass Morone saxatilis & 36 & 2,624 & 20,588 & 91.1 \\
\hline White bass Morone chrysops & 69 & 294 & 2,290 & 19.0 \\
\hline Hybrid striped bass ${ }^{\mathrm{a}}$ & 63 & 1,045 & 8,896 & 4.0 \\
\hline White crappie Pomoxis annularis & 108 & 226 & 2,063 & 4.0 \\
\hline
\end{tabular}

a Striped bass $\times$ white bass.

duction and growth: reservoir surface area, which is a general predictor of fish yield and standing crop (Jenkins and Morais 1971; Hanson and Leggett 1982; Youngs and Heimbuch 1982), and growing-season length (number of frost-free days in the year), which is a general predictor of fish yield (Jenkins and Morais 1971; Schlesinger and Regier 1982) and growth (Tomcko and Pierce 2001; Wilde and Muoneke 2001; Pope et al. 2004). We obtained measures of reservoir surface area from Texas Parks and Wildlife Department's Lake Categorization File, a database of morphometric and biological characteristics of Texas reservoirs. Information on growing-season length was obtained from Ramos (1995).

We used Pearson's product-moment correlation coefficient to assess the relationship between lakerecord weights of fish and reservoir surface area and growing-season length. Reservoir surface area spanned five orders of magnitude, so we use a $\log _{10}$ transformation to reduce skew in this variable. The lake-record weights of fish and growing-season length required no transformation. To limit the probability of falsely rejecting null hypotheses, we used the sequential Bonferroni adjustment (Rice $1989)$ with a tablewide significance level $(\alpha)$ of 0.05 to evaluate correlations. We expected to observe positive correlations for all species between lake-record weights and log surface area (Jenkins and Morais 1971; Hanson and Leggett 1982; Youngs and Heimbuch 1982) and growing-season length (Jenkins and Morais 1971; Schlesinger and Regier 1982). We used one-tailed binomial tests (Siegel 1956) to determine, regardless of the sta- tistical significance of individual tests, whether there was an excess proportion of positive correlations between the lake-record weight of fish and $\log$ surface area and growing-season length. Under the null hypothesis of no correlation, we expected $50 \%$ of the correlations to be positive and $50 \%$ to be negative. All statistical analyses were performed with SAS software (SAS Institute 1999).

\section{Results}

The number of lake-record weights of fish from reservoirs ranged from 25 (longear sunfish) to 196 (largemouth bass). Reservoir surface areas ranged from less than 1 ha to 74,870 ha, and growing seasons ranged from 186 to $341 \mathrm{~d}$ (Table 1). Correlations between the record weights of fish and $\log$ surface area were significant $(P<0.05)$ only for flathead catfish and largemouth bass based on the sequential Bonferroni adjustment (Table 1). No correlation between record weight and growing season was significant based on the sequential Bonferroni adjustment.

Across species and regardless of the significance of individual correlations, we observed an excess proportion of positive correlations (13 of 14; $P<$ 0.0001 ) between the record weights of fish and log surface area. This suggests that lake-record weights of fish caught by anglers show a tendency to increase with reservoir size. We observed no evidence of an excess proportion of positive correlations ( 7 of $14 ; P=0.605$ ) between the record weights of fish and growing season. 
TABLE 1.-Extended.

\begin{tabular}{|c|c|c|c|c|c|}
\hline \multirow[b]{2}{*}{ Species } & \multirow{2}{*}{$\frac{\text { Surface area }(\mathrm{ha})}{\text { Maximum }}$} & \multicolumn{2}{|c|}{ Growing season (d) } & \multicolumn{2}{|c|}{ Correlation $(r)$} \\
\hline & & Minimum & Maximum & $\log _{10}$ surface area & Growing season \\
\hline Black crappie Pomoxis nigromaculatius & $74,869.5$ & 190 & 290 & $0.32 *$ & 0.33 \\
\hline Blue catfish Ictalurus furcatus & $17,806.8$ & 205 & 300 & 0.31 & 0.29 \\
\hline Bluegill Lepomis macrochirus & $36,018.3$ & 190 & 289 & $0.36^{*}$ & 0.13 \\
\hline Channel catfish Ictalurus punctatus & $46,338.2$ & 190 & 341 & $0.43 *$ & -0.09 \\
\hline Common carp Cyprinus carpio & $36,018.3$ & 190 & 341 & $0.50 *$ & -0.02 \\
\hline Flathead catfish Pylodictis olivaris & $36,018.3$ & 190 & 289 & $0.44 * *$ & -0.02 \\
\hline Largemouth bass Micropterus salmoides & $74,869.5$ & 190 & 322 & $0.49 * *$ & 0.08 \\
\hline Longear sunfish Lepomis megalotis & $36,018.3$ & 221 & 274 & 0.26 & 0.49 \\
\hline Redear sunfish Lepomis microlophus & $11,975.9$ & 226 & 278 & 0.25 & $0.51 *$ \\
\hline Smallmouth bass Micropterus dolomieu & $36,018.3$ & 186 & 300 & 0.32 & 0.06 \\
\hline Striped bass Morone saxatilis & $74,869.5$ & 208 & 300 & -0.13 & -0.04 \\
\hline White bass Morone chrysops & $74,869.5$ & 190 & 290 & 0.13 & -0.04 \\
\hline Hybrid striped bass ${ }^{\mathrm{a}}$ & $74,869.5$ & 205 & 300 & 0.15 & -0.07 \\
\hline White crappie Pomoxis annularis & $74,869.5$ & 186 & 300 & $0.26 *$ & -0.08 \\
\hline
\end{tabular}

\section{Discussion}

We observed a direct relationship between the lake-record weights of fish and reservoir surface area. The strength of this relationship varied among species, being strongest in flathead catfish and largemouth bass and less evident in other species studied. Our results for largemouth bass are consistent with those of Hendricks et al. (1995), who observed that angler catch rates of memorable-size $(\geq 2.27 \mathrm{~kg}$ ) black bass Micropterus spp. in tournaments were positively correlated with reservoir surface area. For several species, we believe that the strength of the relationship between record fish weights and reservoir surface area was obscured by the scarcity of established records from smaller reservoirs. This resulted in both small sample sizes for some species (Table 1) and the availability of records from only a limited size range of reservoirs.

The relationship between lake-record weights and surface area implies that, on average, larger water bodies produce larger fish. We expected this result because of the general relationship between reservoir (or lake) size and fish production (Jenkins and Morais 1971; Hanson and Leggett 1982). We reasoned that larger reservoirs produce, on average, a greater mass and number of fish. Therefore, these reservoirs should be better able to support the energetic needs of the largest fish. Further, if fish reach large size because of a fortuitous combination of genetic potential and chance, larger reservoirs again would be expected to outperform smaller reservoirs because they produce greater numbers of individuals and, therefore, have a greater number of tickets in the lottery. Finally, large fish may be less vulnerable to capture in larger reservoirs, allowing them to live longer and reach greater size. Reservoir surface area is inversely related to mean depth (e.g., Ryder 1982), which is itself directly related to lake productivity (Rawson 1952). Therefore, the observed relationship between the record weights of fish and surface area is unlikely to be due to systematic differences among reservoirs in productivity. We note that our results are specific to angled record weights from individual Texas reservoirs and have no necessary bearing on the question of which reservoirs produce the greatest numbers of trophy-size fish.

Growing-season length varied by as much as five months (range $=186-341 \mathrm{~d}$ ) among the reservoirs in our sample, yet we observed no relationship between record weights and growing season. We did not anticipate this result because growth rates of several of our study species-bluegill (Tomcko and Pierce 2001), largemouth bass (Miranda and Durocher 1986), white bass (Wilde and Muoneke 2001), and white crappie (Pope et al. 2004)-are correlated with growing-season length. Our results can be reconciled with those studies by recognizing that they describe mean growth. In any population there will be individuals that grow less than average and those that grow more. Our analyses presumably consider only the small number of individuals that exhibit the greatest growth and consequently reach record weight.

Previous studies of trophy fisheries (e.g., Hughes and Wood 1996; Crawford et al. 2002; Wilson and Dicenzo 2002) have described physical 
and biological characteristics of specific water bodies that appear to be important in producing trophy fish. This approach is particularly useful in identifying factors that might be used as general predictors of the production and abundance of large fish. However, such descriptions frequently consider only one species and emphasize unique features or conditions that would be difficult, if not impossible, to replicate elsewhere. A second approach to assessing conditions favorable for producing trophy or record-weight fish is to compare fish populations from a number of water bodies and determine which general factors are the best predictors of trophy fish production. Such analyses commonly are limited by the quality and quantity of information available on physical and biological characteristics of the study waters. For example, Oglesby (1977) found that nutrient concentrations were better predictors of fish yield than were morphoedaphic characteristics such as mean depth and surface area. Nevertheless, our results show that this approach can provide general insight into mechanisms affecting the production of trophy fish.

\section{Management Implications}

Lake-record weights of fish caught by anglers are directly related to reservoir surface area. This relationship can provide managers with guidance in setting realistic goals for producing trophy-sized fish in smaller water bodies. Despite angler interests and the best management intentions, the maximum size of fish that can be produced in a water body of given size has an upper limit. We believe that scatter plots and regressions of lake-record weights of fish on log surface area might be useful as a preliminary diagnostic tool for management of trophy fisheries. Record weights of fish that are much smaller or larger than expected based on water body size might warrant management attention. Although our study examined a relatively small number of species that were captured from reservoirs, we believe that our results are applicable to other species and types of aquatic habitats. For example, record weights of stream fish captured by anglers are likely to be directly related to watershed or drainage basin area.

Several authors have recommended that fishery managers use angler-supplied catch data with caution (e.g., Gabelhouse and Willis 1986; Lucy and Davy 2000; Crozier and Kennedy 2001). Often fish captured by anglers are, on average, larger than those captured by standard fishery sampling gears. In assessing the potential of a reservoir for pro- ducing trophy-size fish, this bias in angler-supplied data is advantageous because we are interested in samples that indicate maximum, not average or representative, sizes of fish. In addition, use of information from angler recognition programs, as suggested here, may have the benefit of increasing goodwill and communication between management agencies and the angling public (Brown 1996) because use of these data is a clear indication of both angler success in catching desirablesized fish and manager commitment to producing such fish. The potential usefulness of data derived from angler recognition programs in understanding production of trophy-size fish warrants further study. Because sampling gears used by managers (Murphy and Willis 1996) and anglers (Gabelhouse and Willis 1986; Crozier and Kennedy 2001) are selective for certain sizes of fish, a better understanding of the selectivity of angling gears (e.g., Wilde et al. 2003) would facilitate the analysis and interpretation of angler-supplied data.

\section{Acknowledgments}

We thank Christopher J. Chizinski and Bart W. Durham for comments on the manuscript. Funding for this study was provided by Texas Tech University. This is contribution T-9-989 of the College of Agricultural Sciences and Natural Resources, Texas Tech University, Lubbock.

\section{References}

Brown, T. L. 1996. Reservoir fisheries and agency communication. Pages 31-37 in L. E. Miranda and D. R. DeVries, editors. Multidimensional approaches to reservoir fisheries management. American Fisheries Society, Symposium 16, Bethesda, Maryland.

Cofer, L. M. 1994. Evaluation of a trophy bass length limit on Lake Fuqua, Oklahoma. Proceedings of the Annual Conference Southeastern Association of Fish and Wildlife Agencies 47(1993):702-710.

Crawford, S., W. F. Porak, D. J. Renfro, and R. L. Cailteux. 2002. Characteristics of trophy bass populations in Florida. Pages 567-581 in D. P. Philipp and M. S. Ridgway, editors. Black bass: ecology, conservation, and management. American Fisheries Society, Symposium 31, Bethesda, Maryland.

Crozier, W. W., and G. J. A. Kennedy. 2001. Relationship between freshwater angling catch of Atlantic salmon and stock size in the River Brush, Northern Ireland. Journal of Fish Biology 58:240-247.

Driver, B. L. 1985. Specifying what is produced by management of wildlife by public agencies. Leisure Sciences 7:281-294.

Driver, B. L., and R. W. Cooksey. 1980. Preferred psychological outcomes of recreational fishing. Pages 27-40 in R. A. Barnhart and T. D. Roelofs, editors. Catch-and-release fishing as a management tool: a 
national sport fishing symposium. Humbolt State University, Arcata, California.

Falk, J. M., A. R. Graefe, and R. B. Ditton. 1989. Patterns and participation and motivation among saltwater tournament anglers. Fisheries 10(4):10-17.

Fedler, A. J., and R. B. Ditton. 1986. A framework for understanding the consumptive orientation of recreational fishermen. Environmental Management 10:221-227.

Fedler, A. J., and R. B. Ditton. 1994. Understanding angler motivations in fisheries management. Fisheries 19(4):6-13.

Fisher, M. R. 1997. Segmentation of the angler population by catch preference, participation, and experience: a management-oriented application of recreation specialization. North American Journal of Fisheries Management 17:1-10.

Forshage, A. A., P. P. Durocher, M. A. Webb, and D. G. Lewis. 1990. Management application of angler recognition program data. Proceedings of the Annual Conference Southeastern Association of Fish and Wildlife Agencies 43(1989):36-40.

Gabelhouse, D. W., Jr. 1984. A length-categorization system to assess fish species. North American Journal of Fisheries Management 4:273-285.

Gabelhouse, D. W., Jr., and D. W. Willis. 1986. Biases and utility of angler catch data for assessing size structure and density of largemouth bass. North American Journal of Fisheries Management 6:481489.

Gilliland, E. R., and J. Whitaker. 1990. Introgression of Florida largemouth bass introduced into northern largemouth bass populations in Oklahoma reservoirs. Proceedings of the Annual Conference Southeastern Association of Fish and Wildlife Agencies 43(1989): 182-190.

Hanson, J. M., and W. C. Leggett. 1982. Empirical prediction of fish biomass and yield. Canadian Journal of Fisheries and Aquatic Sciences 39:257-263.

Hendricks, A. S., M. J. Maceina, and W. C. Reeves. 1995. Abiotic and biotic factors related to black bass fishing quality in Alabama. Lake and Reservoir Management 11:47-56.

Horton, R. A., and E. R. Gilliland. 1994. Monitoring trophy largemouth bass in Oklahoma using a taxidermist network. Proceedings of the Annual Conference Southeastern Association of Fish and Wildlife Agencies 47(1993):679-685.

Hudgins, M. D. 1984. Structure of the angling experience. Transactions of the American Fisheries Society 113:750-759.

Hughes, J. S., and M. G. Wood. 1996. Development of a trophy largemouth bass fishery in Louisiana. Proceedings of the Annual Conference Southeastern Association of Fish and Wildlife Agencies 49(1995):58-68.

Jenkins, R. M., and D. I. Morais. 1971. Reservoir sport fishery effort and harvest in relation to environmental variables. Pages 371-384 in G. E. Hall, editor. Reservoir fisheries and limnology. American Fisheries Society, Special Publication 8, Bethesda, Maryland.
Lucy, J., and K. Davy. 2000. Benefits of angler-assisted tag and release programs. Fisheries 25(4):18-23.

Miranda, L. E., and P. P. Durocher. 1986. Effects of environmental factors on growth of largemouth bass in Texas reservoirs. Pages 115-121 in G. E. Hall and M. J. Van Den Avyle, editors. Reservoir fisheries management: strategies for the 80's. American Fisheries Society, Southern Division, Reservoir Committee, Bethesda, Maryland.

Modde, T., and C. G. Scalet. 1985. Latitudinal growth effects on predator-prey interactions between largemouth bass and bluegills in ponds. North American Journal of Fisheries Management 5:227232.

Murphy, B. R., and D. W. Willis. 1996. Fisheries techniques, 2nd edition. American Fisheries Society, Bethesda, Maryland.

Oglesby, R. T. 1977. Relationships of fish yield to lake phytoplankton standing crop, production, and morphoedaphic factors. Journal of the Fisheries Research Board of Canada 34:2271-2279.

Petering, R. W., G. L. Isbell, and R. L. Miller. 1995. A survey method for determining angler preferences for catches of various length and number combinations. North American Journal of Fisheries Management 15:732-735.

Pope, K. L., G. R. Wilde, and B. W. Durham. 2004. Age-specific patterns in density-dependent growth of white crappie, Pomoxis annularis. Fisheries Management and Ecology 11:33-38.

Quinn, S. P. 1987. The status and usefulness of angler recognition programs in the United States. Fisheries 12(2):10-16.

Ramos, M. G. 1995. The Texas almanac. A. H. Belo Corporation, Dallas, Texas.

Rawson, D. S. 1952. Mean depth and the fish production of large lakes. Ecology 33:513-521.

Rice, W. R. 1989. Analyzing tables of statistical tests. Evolution 43:223-225.

Ryder, R. A. 1982. The morphoedaphic index: use, abuse, and fundamental concepts. Transactions of the American Fisheries Society 111:154-164.

SAS Institute. 1999. SAS, release 8.0. SAS Institute, Cary, North Carolina.

Schlesinger, D. A., and H. A. Regier. 1982. Climatic and morphoedaphic indices of fish yields from natural lakes. Transactions of the American Fisheries Society 111:141-150.

Siegel, S. 1956. Nonparametric statistics for the behavioral sciences. McGraw-Hill, New York.

Spencer, P. D. 1993. Factors influencing satisfaction of anglers on Lake Miltona, Minnesota. North American Journal of Fisheries Management 13:201-209.

Tomcko, C. M., and R. B. Pierce. 2001. The relationship of bluegill growth, lake morphometry, and water quality in Minnesota. Transactions of the American Fisheries Society 130:317-321.

Wilde, G. R., and R. B. Ditton. 1994. A managementoriented approach to understanding diversity among largemouth bass anglers. North American Journal of Fisheries Management 14:34-40.

Wilde, G. R., and R. B. Ditton. 2000. Differences in 
attitudes and fishing motivations among Texas catfish anglers. Pages 395-405 in E. R. Irwin, W. A. Hubert, C. F. Rabeni, H. L. Schramm, Jr., and T. Coon, editors. Catfish 2000: proceedings of the first international ictalurid symposium. American Fisheries Society, Symposium 24, Bethesda, Maryland.

Wilde, G. R., and M. I. Muoneke. 2001. Climate-related and morphoedaphic correlates of growth in white bass. Journal of Fish Biology 58:453-461.

Wilde, G. R., K. L. Pope, and B. W. Durham. 2003. Lure-size restrictions in recreational fisheries. Fisheries 28(6):18-26.

Wilde, G. R., R. K. Riechers, and R. B. Ditton. 1998.
Differences in attitudes, motives, and demographic characteristics between tournament and nontournament Texas black bass anglers. North American Journal of Fisheries Management 18:422-431.

Wilson, D. M., and V. J. Dicenzo. 2002. Profile of a trophy largemouth bass fishery in Briery Creek Lake, Virginia. Pages 583-592 in D. P. Philipp and M. S. Ridgway, editors. Black bass: ecology, conservation, and management. American Fisheries Society, Symposium 31, Bethesda, Maryland.

Youngs, W. D., and D. G. Heimbuch. 1982. Another consideration of the morphoedaphic index. Transactions of the American Fisheries Society 111:151153. 